are "... no obligatory combinations of deficits."

This monograph bears a deceptively simple title. The large number of reported observations and studies, the methodological problems involved, and the moot or uninvestigated questions that emerge from such a seemingly circumscribed topic indeed present broad challenges to investigators in several areas of neurology, psychiatry, and psychology. This work, however, is certainly not a mere bombardment of confounding material. It is a compendium of case studies, clinical observations and im- pressionistic conceptions and empirical investigations and hypotheses. The clear exposition of equivocal findings and assumptions and unexplored problems offers a wealth of stimulating ideas for research and thought. The methodological deficiencies of past work are brought to light and techniques of systematic, objective behavioral analysis are demonstrated. Finally, in this volume Dr. Benton, his associates, and many others clearly exemplify the types of benefits which may evolve from the stimulation of interdisciplinary research. H. F. Wahler

\title{
BOOKS AND PAMPHLETS RECEIVED
}

Bickel, Lothar. The Unity of Body and Mind. Edited and translated by Walter Bernard. New York: Philosophical Library, 1959. pp. 167. \$3.75.

Brody, Morris W., M.D. Observations on Direct Analysis: The Therapeutic Technique of Dr. Fohn N. Rosen. New York: Vantage Press, 1959. pp. 104. $\$ 2.95$.

Burmeister, Eva. The Professional Houseparent. New York: Columbia University Press, 1960. pp. 244. \$4.

Farber, Bernard. Family Organization and Crisis: Maintenance of Integration in Families with a Severely Mentally Retarded Child. Monogr. Soc. Res. Child Develpm., 25 : No. 1, Serial No. 75, 1960. Lafayette, Indiana: Child Development Publications, Purdue University, 1960. pp. 95. $\$ 2.75$.

Farnsworth, Paul R., and Quinn McNemar (Eds.) Annual Review of Psychology, Vol. 11. Palo Alto, Calif.: Annual Reviews, 1960. pp. 544. \$7 U.S.A.; $\$ 7.50$ elsewhere.

Finn, Michael H. P., Ph.D., and Fred Brown, Ph.D. (Eds.). Training for Clinical Psychology: Proceedings of the SpringfieldMount Sinai Conferences on Intern Training in Clinical Psychology. New York:
International Universities Press, 1959. pp. 186. \$4.

Freund, Hans. The Balanced Life: An Essay in Ethics. New York: Philosophical Library, 1959. pp. 186. $\$ 4.50$.

Fujisawa, Chikao, Ph.D. Zen and Shinto: $A$ History of Fapanese Philosophy. New York: Philosophical Library, 1959. pp. 92. $\$ 2.75$.

Group for the Advancement of Psychiatry, Committee on Mental Retardation. Basic Considerations in Mental Retardation: $A$ Preliminary Report. (Report No. 43). New York: GAP, 1959. pp. 25. 40 cents.

Health Education Monographs, Nos. 4, 5, and 6, 1959. Oakland, Calif.: Society of Public Health Educators, 1959. \$1 each.

Jastak, J. F. The Jastak Test of Potential Ability and Behavior Stability: Short Form. Minneapolis: Educational Test Bureau, Educational Publishers, 1959. Specimen Set, $\$ 1.25$.

La Barre, Weston. The Peyote Cult. (Originally published as Yale University Publications in Anthropology, No. 19. Reprinted by permission of the Department of Anthropology, Yale University.) 
Hamden, Conn.: Shoe String Press, 1959. pp. 188 plus plates. $\$ 4$.

Leeper, Robert Ward, and Peter Madison. Toward Understanding Human Personalities. New York: Appleton-CenturyCrofts, 1959. pp. 439. \$5.50.

McKinney, Fred. Personal Adjustment: Students' Introduction to Mental Hygiene. 3d ed. New York: Wiley, 1960. pp. 490. $\$ 6.50$.

Proceedings of the Seventh Biennial AlumniFaculty Conference of the Graduate School of Social Work, University of Pittsburgh. Theme: Social Change-Implications for Social Work Education and Practice. Held in cooperation with the Pittsburgh $\mathrm{Bi}$ centennial, April 17-18, 1959. Pittsburgh : Graduate School of Social Work, University of Pittsburgh, 1959. pp. 64.

Redl, Fritz, Ph.D. Pre-Adolescents: What Makes Them Tick? Revised ed. New York: Child Study Association of America, Dec. 1959. pp. 28.25 cents.

Spitz, René A., M.D. A Genetic Field Theory of Ego Formation: Its Implications for Pathology. Freud Anniversary Lecture Series, New York Psychoanalytic Institute. New York: International Universities Press, 1959. pp. 123. \$3.

Sutherland, Robert L., Ph.D., and Eugene C. MacDanald, Jr., M.D. Conformity and the Inner Self. (Reprinted with permission from the Gournal of the National As- sociation of Women Deans and Counselors, Vol. XXI, No. 4, June 1958.) Austin: Hogg Foundation for Mental Health, University of Texas, 1959. pp. 14. 20 cents.

Terman, Lewis M., and Maud A. Merrill. Stanford-Binet Intelligence Scale: Manual for the Third Revision, Form L-M. (With revised IQ tables by Samuel R. Pinneau.) Boston: Houghton Mifflin, 1960. pp. 363. $\$ 5$.

Titchener, James L., M.D., and Maurice Levine, M.D. Surgery as a Human Experience: The Psychodynamics of Surgical Practice. New York: Oxford University Press, 1960. pp. 285. \$6.

U. S. Department of Health, Education, and Welfare. Preparation of Mentally Retarded Youth for Gainful Employment. Office of Education Bull. 1959, No. 28; Office of Vocational Rehabilitation, Rehabilitation Service Series No. 507. Washington: U. S. Government Printing Office, 1959. pp. 86.35 cents.

World Health Organization. Mental Health Problems of Automation: Report of a Study Group. WHO Technical Report Series No. 183. Palais des Nations, Geneva: WHO, 1959. pp. 30.30 cents. (Columbia University Press, International Documents Service, 2960 Broadway, New York 27.) 